Regulating the globalised economy perspəctive

Through Perspective CIRAD provides the opportunity to explore new avenues for discussion and action based on research and expertise, without presenting an institutional position.

Articulating private

\title{
voluntary standards
} and public regulations

Marcel Djama

How can the social and environmental impact of economic globalisation be reduced? Faced with the deadlock of inter-State negotiations aimed at implementing collective action, private actors - multinational companies and NGOs - are developing standards of "good" social and environmental practice, such as forest certification or standards regarding working conditions.

Some people believe that the proliferation of these voluntary standards reflects the privatisation of sustainable development policy. Yet private standards and public regulations are often complementary and work in synergy; synergies that must be consolidated

The last 20 years have seen a considerable increase in the number of standards aimed at establishing rules on good social and environmental practice; sustainable development standards. These standards aim to regulate a sector of activity or an industrial sector as a whole; in this they differ from the codes of conduct or corporate social responsibility policies that some companies are developing.

The first initiatives emerged in the wake of the Rio Summit (1992); they adopted criteria that could be applied without distinction to several sectors of activity. In the 2000s, the goal was to target the most polluting industries, which led to the development of sectoral standards. In the late 2000s, faced with the proliferation of standards, it became necessary to codify the way standards were developed.

These private standardisation mechanisms have developed in several sectors of activity - extractive industries, apparel, finance etc. They target fields of action as diverse as the environment, financial transparency, "good governance", human rights and the social rights of workers.

These voluntary standards are proposed by private actors - multinationals, NGOs (nongovernmental organisations) - in a given sector of activity. They are developed in consultation with the people concerned, and are subject to monitoring and certification procedures. 
The definition of good practice is now increasingly based on partnerships between private operators.

Types of voluntary private standards
According to some observers, these standards are one of the main institutional innovations of recent years. Indeed, long confined to the realm of the responsibility of the public authorities or professional bodies, the definition of "good practice" is now increasingly based on partnerships between private operators. New consultation frameworks have therefore emerged, in which a dialogue is established between the individuals or social groups concerned by the problems caused by an industrial activity: producers (farmers, foresters, miners, etc.), industries (processing, distribution, etc.), local communities or resident groups, social, environmental or human rights NGOs, bankers and investors, etc. Stakeholders therefore have less direct contact with the public authorities.

- Corporate codes of conduct are produced by companies to define guidelines for their action and to prohibit certain behaviour that has an adverse social or environmental effect. The company may impose the code of conduct on its suppliers.

- Multi-stakeholder initiatives are based on cooperation to develop standards in one or more fields (working conditions, environment, corruption, etc.) of a sector of activity. They may lead to a third party certification process, or to a label.

- Certification and labels are produced by accredited organisations. They are based on social or environmental audits. Their goal is to provide buyers (consumers or industries) with reliable information enabling them to adjust their purchasing decisions.

- Meta-standards are developed by coalitions of standards organisations. They establish frameworks and guiding principles for ensuring coherence between several standardisation mechanisms. For example, the new ISO 26000 standard defines a framework for drawing up corporate charters on social and environmental responsibility; and the International Social and Environmental Accreditation and Labelling Alliance (ISEAL) coordinates the main multi-stakeholder initiatives and accreditation organisations in order to improve standards.

Source: OCDE, FAO.

\section{The agro-food industry and forestry, two leading sectors}

The agro-food industry and forestry are among the most dynamic and innovative sectors. Alone, they boast more than 10 transnational schemes aimed at promoting sustainable development standards.

In practice, most of these standards take the form of specifications defining principles and criteria that govern the production and processing methods for a product. These principles and criteria are developed in the name of a consensual approach to sustainable development, established by stakeholders. Finally, in order to make standards more credible, most mechanisms are based on third party certification, which monitors compliance with the principles and criteria, as well as product traceability.

In addition to the fact that they are the result of a partnership between NGOs and companies, private voluntary standards developed in the name of sustainable development share four common characteristics.

First, the intended scale of regulation is transnational: the aim is to produce rules whose field of application transcends nation-State borders. Second, governance is a central element. A considerable share of activities and resources is devoted to the implementation of participation, consultation and deliberation procedures. The legitimacy of standards is thus based on both a balanced representation of stakeholders and on their capacity to provide solutions to the social and environmental problems generated by the industry. Third, standardsetting organisations seek to become institutionalised and to establish themselves as regulatory instruments. To do so, they strive to involve as many industries as possible. Finally, all of these mechanisms are based on the law of supply and demand as the ultimate judge of "good practice". The need to distinguish virtuous firms from others explains the role given to traceability, monitoring and certification processes. 


\section{The evolution of multi-stakeholder private voluntary standards}

1972-1998

MULTI-

SECTOR

STANDARDS

1993-2006

PRODUCT-

ORIENTED

STANDARDS

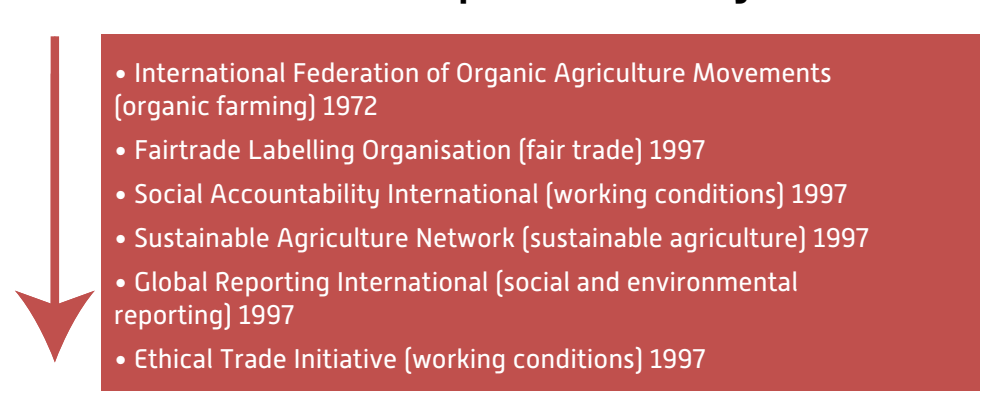

- Forest Stewardship Council (forest) 1993

- Marine Stewardship Council [fisheries] 1997

- Ethical Tea Partnership (tea] 1997

- Flower Label Programme (cut flowers) 1998

- Marine Aquarium Council (marine ornementals) 1998

- Programme for the Endorsement of Forest Certification (forest) 1999

- Roundtable on Sustainable Palm Oil [palm oil) 2003

- Common Code for the Coffee Community (coffee) 2004

- Roundtable on Responsible Soy (soya) 2005

- Better Sugarcane Initiative (sugar cane) 2005

- Better Cotton Initiative (cotton) 2006

- Roundtable on Sustainable Biofuel (biofuels] 2006

2006-2010 META-

STANDARDS

- ISEAL Alliance [standards and accreditation process) 2003

- ISO 26000 (guidance for social responsability) 2010

\section{Towards private transnational governance?}

Because of their characteristics, private voluntary standards are emblematic of regulatory organisations known as "private transnational authorities". Indeed, they produce rules seen as legitimate by the actors they apply to and, moreover, by certain States; and they implement monitoring and sanctions procedures in case of non-compliance with the rules. Some people believe that

The linkages between sustainable standards and public regulations are proving far more complex than would appear from the recurrent discussions on State withdrawal.
Moreover, although they illustrate the growing role of non-State actors in global policy, the linkages between sustainable standards and public regulations are proving far more complex than would appear from the recurrent discussions on State withdrawal. Indeed, private voluntary standards have often been promoted by States, who see them as a means of imposing environmental and social standards at the international level. The use of private operators, tasked with raising consumer awareness and putting pressure on firms, appears as a means of circumventing the rules imposed by the WTO (World Trade Organization) and lessening the attractiveness of countries with limited environmental and social constraints. For example, it was the US authorities (the Clinton administration) that fostered, in the 1990s, the rapid development of non-governmental organisations promoting social standards, such as Social Accountability International (SAI) and the Fair Labor Association (FLA). The aim at the time was to limit the risks of offshoring to countries with fewer social and environmental regulations, further to the entry into force of the North American Free Trade Agreement (NAFTA). More generally speaking, several private voluntary initiatives benefit or have benefited from the financial support of States, from the European Union or the United States for the majority, that want to promote the international dissemination of sustainable development standards.

State support also works in an incentive manner: fiscal facilities granted to companies that adopt sustainable development standards; or the introduction of preferential clauses in public procurement or purchasing policies. For example, local authorities may decide to only source certified products from sustainably managed forests or fair trade.

These regulatory instruments are becoming institutionalised and are therefore being deployed according to a hybrid logic, mobilising the public authorities and the private sector. This observation goes against an academic literature that considers - for better or worse - that the rise of private voluntary standards is an indicator of the decline of the State. 


\section{Potential synergies between public regulation and private standards}

Private voluntary standards help to reinforce public regulations in the countries in which

producers and companies operate.

A few words about...

Marcel DJAMA is a social science researcher in the MOISA

joint research unit, Markets, organisations, institutions and stakeholder strategies [http://umr-moisa.cirad.fr/]. His research centres on the internationalisation of environmental and agricultural policies and their local and national effects. He focuses particularly on social movements (especially the mobilisation of local and indigenous communities] and the growing role of non-State actors (firms and NCOs) in global policy. marcel.djama@cirad.fr

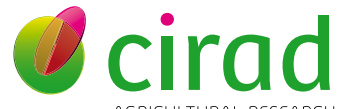

AGRICULTURAL RESEARCH FOR DEVELOPMENT 42, rue Scheffer 75116 Paris . FRANCE

www.cirad.fr

perspactive

Editor: Patrick Caron,

Deputy Director General of Research and Strategy

Coordination: Corinne Cohen

Department for Scientific and Technical

Information

Graphic design: Patricia Doucet

Communication Service
The linkages between private voluntary standards and public regulations do in fact exist, and would benefit from being more clearly highlighted and systematised.

Paradoxically, private voluntary standards help to reinforce public regulations in the countries in which producers and companies operate. Indeed, the standards adopt as an underlying principle the compliance of their members with national laws and regulations. Moreover, independent monitoring procedures verify the correct application of laws and thereby help to correct the shortcomings of certain States in this matter.

Furthermore, voluntary standards are an area for producing and testing innovations that

This Perspective is based on research conducted as part of the NORMES project. Financed by the French National Research Agency (Agriculture and sustainable development programme, ANR-06-PADD-013), this project was carried out by CIRAD in partnership with IDDRI (Institute for Sustainable Development and International Relations) and INRA (French National Institute for Agricultural Research). Several CIRAD researchers from the MOISA joint research unit were involved: Emmanuelle Cheyns, Benoit Daviron, Marcel Djama, Ève Fouilleux, Stéphane Guéneau and Isabelle Vagneron

This research has led to several publications, including:

- Djama M., Fouilleux E., Vagneron I., 2011. Standard-setting, certifying and benchmarking. A governmentality approach to sustainability standards in the Agro-Food sector. In Ponte S., Vestegaard J., Gibbon P. (eds.), Governing through Standards: Origins, drivers and limits. London: Palgrave.

- Djama M. 2010. Le « complexe industriesONG » et la procédure de constitution d'un standard de « développement durable ». In Droit

\section{TO FIND OUT MORE}

Bartley T., 2007. Institutional emergence in an era of globalization: the rise of transnational private regulation of labor and environmental conditions. American Journal of Sociology, vol. 113 (2), 297-351.

Carey Ch. \& Guttenstein E., 2008. Governmental use of voluntary standards: innovation in sustainability gov-
States can then integrate into their public policy. For example, instruments for the identification and zoning of high conservation value (HCV) areas, one of the components of FSC forest certification, have been adopted as such by States (China, Bolivia, etc.) or by regional authorities in their regional planning policies.

Finally, transparency and impartiality concerns may also lead States to outsource some of their regulatory prerogatives, using private voluntary standards. By delegating the inspection and traceability of imported "sustainable" goods to private certification bodies, States are secured against having a suspected protectionist agenda in their trade policy.

Rather than setting private voluntary standards against public regulations, existing or potential complementarities and synergies should therefore be further explored.

de Cités, n 15, March 2010, http://droitdecites. org/2010/03/15/marcel-djama/

- Cheyns E., 2011. Multi-stakeholder initiatives for sustainable agriculture: The limits of the 'inclusiveness' paradigm. In Ponte S., Vestergaard J. \& Gibbon P. (eds.), Governing through standards: Origins, drivers and limits. London: Palgrave.

- Daviron B., Vagneron I., 2011. From commoditization to de-commoditization... and back again? Discussing the role of the new sustainable standards. Development Policy Review, 29 (1): 91-112.

- Fouilleux È., 2010. Les standards volontaires entre internationalisation et privatisation des politiques agricoles. In Hervieu B. et al., Les Mondes agricoles en politique, Presses de Sciences Po, Paris, p. 371-396.

- Guéneau S., 2009. Certification as a new private global forest governance system: The regulatory potential of the Forest Stewardship Council. In Peters A., Koechlin L., Föster T., Fenner Zinkernagel G. Non-State Actors as Standard Setters, Cambridge: Cambridge University Press: $379-408$

ernance. ISEAL Alliance \& Trade Standards Practitioners Network Report 079: London UK.

FAO, 2003. Normes environnementales et sociales, certification et labellisation des cultures commerciales. Rome : FAO, 111 p.

Pattberg Ph., 2007. Private institutions and global governance. The new politics of environmental sustainability. Cheltenham (UK): Edward Elgar Publishing Limited. 